\title{
The Comparative and International Education Society of Canada (CIESC) ${ }^{1}$
}

\author{
Suzanne Majhanovich (The University of Western Ontario) \\ Zhang Lanlin (The University of Western Ontario)
}

The Comparative and International Education Society of Canada/Société canadienne d'éducation comparée et internationale (CIESC/SCECI) was established on 5 June 1967. As an educational society in an officially-bilingual country, the society from the outset has been a bilingual organisation with its constitution in both English and French. Conference papers may be in either language, and the society's journal also publishes in both English and French. In 1970 the CIESC hosted the $1^{\text {st }}$ World Congress of Comparative Education Societies in Ottawa; and in 1989 the CIESC hosted the $7^{\text {th }}$ World Congress in Montreal.

This chapter presents a history of the development of the CIESC, touching on its context and epistemological foundations. The society's characteristics are discussed and its activities are presented. The foci include CIESC members' international leadership, the journal, awards, and academic endeavours. The concluding section comments on challenges and future directions.

\section{Birth and Development of the CIESC}

The birth of the CIESC was itself a story of international education development. Andrew F. Skinner, the first CIESC Vice-President and the second President, reported in the first issue of the society's journal (1972, p.4), Canadian and International Education, that the society was "conceived in Vancouver, born and named in Chicago, confirmed in Ottawa, and fostered by a loyal and keen nucleus of founding members and by much appreciated financial sustenance from friendly encouraging sources".

The initiative to form the CIESC was taken by Joseph P. Katz of the University of British Columbia. In March 1966, Katz contacted a number of Canadian educators to express his conviction that there was a place for such an organisation in Canada, either as a branch of what was then called the

\footnotetext{
${ }^{1}$ This article is an expansion of an earlier version by Song Yijun and David N. Wilson and is in press as a chapter in Masemann, V., Bray, M., \& Manzon, M. (eds). Common Interests, Uncommon Goals: Histories of the World Council of Comparative Education Societies and its Members. Hong Kong: CERC Publications. Because 2007 marks the $40^{\text {th }}$ anniversary of the CIESC, the chapter is again expanded by the authors and included here with permission of the Book editors, to inform members of the background of our Society.
} 
Comparative Education Society (CES) in the United States, or as a separate though cooperating entity. Many founding members were graduates from the United States and members of the CES. Katz proposed seven objectives for the society (Gillett et al. 1967, p.9):

- to promote comparative analyses of educational systems within Canada;

- to contribute to better overall planning in education;

- to establish better and more frequent communication among Canadian colleagues in the field of comparative and international education;

- to plan Canadian overseas education seminars;

- to facilitate the exchange of students in the field of comparative and international education;

- to explore ways and means of cooperating with the various organisations and agencies working in international education; and

- to assist in the development of programs for accommodation of foreign students in Canadian colleges and universities.

The founding meeting at Chicago was planned by Katz as a regional gathering during the annual CES conference. The Director of the Comparative Education Center at the University of Chicago, C. Arnold Anderson, agreed to schedule a half day on 14 February 1967 for papers from the nascent Canadian group. Three papers provided overviews of education in Quebec, Ontario and Western Canada. Subsequently the three papers, plus a fourth by Colin H. Smith about adult education in Mid-Western Nigeria, appeared in the first CIESC publication entitled Founding Papers: The New Look in Canadian Education (Gillett et al. 1967). Katz was unanimously elected Provisional Chairman by the 20 Canadians present in Chicago. Participants discussed whether the proposed Canadian society should be an independent association or a regional chapter or affiliate of the CES. Gerald Read, the CES representative, noted that the US society welcomed all interested members, and suggested that the Canadian society might wish to begin as a local chapter of the US society and decide later whether to form a separate and independent association (Gillett et al. 1967, p.11).

As a result of this discussion, the following motion was proposed: "That a provisional committee be formed to explore the best type of organisation and purpose for a Canadian group; such exploration should cover the possibility of becoming a local chapter of the Comparative Education Society, or an independent Canadian society, or some other type of association". The motion was carried unanimously. The other elected members of the Provisional Committee were Margaret Gillett (McGill), Secretary; Robert Lawson (Calgary), Treasurer; and Andrew F. Skinner (Toronto) and Colin Smith (Simon Fraser University), Members-at-large. Two other members were subsequently co-opted to represent Francophone Canada and the Atlantic Provinces: Edouard Trudeau (Collège Jean-de-Brébeuf, Montréal) and Alexander.S. Mowat (Dalhousie).

The provisional committee opted for an independent Canadian society, albeit one that would seek contact and possible affiliation with the US and European societies. At the Learned Societies Conference at Ottawa in June 1967,

2 Canadian and International Education Vol. 36 no.1 -June 2007 
at the request of Joseph Katz, Anthony Paplauskas-Ramunas who was then director of the Comparative Education Centre of the University of Ottawa scheduled the Canadian-based meeting which reviewed programmes and unanimously adopted the English and French versions of the CIESC Constitution. According to Article 1, Section 2 of the Constitution (Gillett et al. 1967, p.18), the purpose of the society was to encourage and promote comparative and international studies in Canadian education by:

1. promoting and improving the teaching of comparative education in institutions of higher learning;

2. stimulating research;

3. facilitating the publication and distribution of comparative studies in education;

4. interesting professors and teachers of other disciplines in the comparative and international dimensions of their work;

5. encouraging visits by educators to study educational institutions and systems throughout the world;

6. co-operating with those in other disciplines who attempt to interpret educational developments in a broad cultural context;

7. organising conferences and meetings;

8. co-operating with comparative and international education societies and with governmental and private agencies in order to further common objectives; and

9. co-operating with other Canadian educational societies to further common objectives.

The Founding Papers listed as members 42 people and one institution, the Ministry of Education of the Province of Quebec (Gillett et al. 1967, pp.74-76). Greetings to the new society were sent from the comparative education societies of Japan, Europe, and the United States, from the International Bureau of Education (IBE) in Switzerland, and from Joseph Lauwerys of Great Britain who was a Past-President of the Comparative Education Society in Europe (CESE). The Provisional Executive elected at Chicago was confirmed in office and augmented by the election of Edouard Trudeau and Alexander S. Mowat as VicePresidents. It was decided to publish a periodical newsletter.

The international education component of the society was acknowledged from the very outset, not only in the constitution but also in the Ottawa conference. The conference programme included an address by a member of the Governmental External Aid Office, W.D. Coombs, on activities of his office and on funding possibilities. Colin Smith spoke of his experiences as an educational adviser in developing countries, and subsequent discussion revolved around ways that the CIESC could contribute to international education development through evaluation of aid programmes (Gillett et al. 1967, p.14).

During the initial years, CIESC meetings were held in conjunction with the annual meetings of the Council of the Learned Societies. Hence, after the founding meeting in Ottawa in 1967, the first actual conference of the CIESC took 
place on 31 May and 1 June 1968 at the University of Calgary. The theme was 'The International Mosaic in Canadian Education', which included talks on Canada's external aid programmes, International Action Groups, CUSO (Canadian University Service Overseas), CYC (Company of Young Canadians), Peace Corps, VSO (Voluntary Service Overseas), a report by Roger Magnusson on the status of comparative education in Canada based on a survey, and a panel entitled 'Foreign Influences in Canadian Education' with papers outlining Scottish influence (Andrew Skinner), French influence (Louis-Philippe Audet), English influence (Willard Brehaut) and American influence (Rudy L. Schnell) for which Gerald Read was discussant (Braham et al. 1968, pp.87-88).

Joseph Katz was not only the driving force behind the establishment of the CIESC, but also an important initiator of international activities related to comparative education. David Wilson (1994a) recalls a heated 1964 exchange between Anderson and Katz at the Comparative Education Center in Chicago, USA, which in part contributed to the change of name of the Comparative Education Society in the United States to the Comparative and International Education Society (CIES).

As early as 1960, Katz had advanced the idea of the International Year of Education. His idea was realised a decade later. In order to mark this event, he proposed the formation of the World Council of Comparative Education Societies (WCCES). He brought the WCCES founding members together in Calgary in 1969 to plan the Council's inaugural World Congress which took place in Ottawa in 1970. The CIESC in cooperation with the Canadian International Development Agency (CIDA), the Canadian National Commission for UNESCO, and four other comparative education societies hosted the $1^{\text {st }}$ World Congress of Comparative Education Societies in Ottawa on 17-21 August 1970. Its three main aims were to establish a Council and a continuing congress, to discuss the place of comparative and international education in the education of teachers, and to examine the role and rationale for educational aid to developing countries (Katz, 1970). Joseph Katz was the Council's first president.

Lifelong learning was an important theme of the 1970 International Education Year, with a focus on adult and higher education. The theme of the 1970 CIESC conference, held in Winnipeg during the Conference of the Learned Societies was 'Comparative Studies in Higher Education'. Papers addressed issues of community colleges, federal-provincial relationships, changing roles of universities, teacher preparation, and a comparison of higher education in Australia and Canada (Skinner, 1970a, pp.115-116). The Canadian Society for the Study of Higher Education (CSSHE) was also founded in 1970, and the CIESC invited members of that society to attend its meeting (Skinner 1970, p.8). The connection between the CIESC and the CSSHE as well as the Canadian Society for Studies in Adult Education (CSSAE) continues, with some members active in both the CIESC and either or both of the other associations. During the annual conference, later called the Congress of Humanities and Social Sciences, it became common to have co-sponsored sessions by the CIESC and the CSSHE or the CSSAE.

4 Canadian and International Education Vol. 36 no.1 -June 2007 
The year 1972 saw two events of significance for the CIESC. First, the society launched its journal Canadian and International Education (CIE) published by the Ontario Institute for Studies in Education (OISE) and "devoted to the publication of articles dealing with education and society in Canada and other nations" (inside cover, Vol.1, No.1). The word 'Comparative' did not appear in the title of the journal, but it is clear that the founders of the journal expected that articles dealing either with issues in Canadian education or in an international context would employ comparative approaches. As Skinner (1972, p.5) noted regarding the early publications of the CIESC and its journal:

It may be observed, and observed correctly, that in these publications attention has to a great degree been focussed upon education in Canada and its provincial and interprovincial features and issues. This is not surprising, indeed it was a matter of deliberate policy. Canada itself, within its own very extensive boundaries, offers wide scope and opportunity for enlightening comparative studies in education. (...) On the other hand a substantial number of other papers offer international content and sustain international perspective, dealing as they do in comparative terms with problems and features in both developed and developing countries.

Since then the journal has normally been published twice a year in June and December, although some years have seen three issues including one special guest-edited issue.

In the first issue the Editor, Shiu Kong, offered the journal as a place where "Canadian comparative educators [could] share their thoughts, research findings, and insights with educators abroad, and ... invite interchange of ideas and experience" (p.1). Andrew Skinner provided a "transition note for the record" (Skinner, 1972), celebrating that the new CIESC organisation had developed to the extent that it had moved beyond the publication of mere papers from the annual congress as a Proceedings to the point where it could launch its own journal. Seven articles included focus on the multicultural curriculum (Katz, 1972), the politics of language and teaching in Quebec (Farine, 1972), and education in China, Romania and developing areas. The CIE journal has had several homes besides the Ontario Institute for Studies in Education. These include the University of Western Ontario, the University of Saskatchewan, Ryerson University, the Chinese University of Hong Kong in conjunction with Brandon University (while the editor, Jack Lam, a Brandon professor was on an extended leave of absence from his home university and was working at the Chinese University of Hong Kong), and Queen's University.

The second momentous event of 1972 was the founding of the Canadian Society for the Study of Education (CSSE) which was organised during the Montreal Conference of the Learned Societies. The CIESC was one of five founding associations, and Avigdor Farine was a member of its first executive board (CIESC Newsletter, June 1972). The CSSE is an umbrella organisation for various education society affiliates. Hence membership in both the CSSE and the CIESC is a requirement for CIESC members - something that could cause 
difficulties for international scholars interested only in the CIESC. The June 1973 CIESC Newsletter reported that the CSSE had revised its structure to accommodate the CIESC members. CSSE members could elect to join any or all of the affiliated groups, but international members concerned only with the activities of the CIESC could apply directly to the CIESC for membership, and would receive a subscription to the CIE journal as part of the membership fee (CIESC Newsletter, June 1973). The affiliation of the CIESC to the umbrella CSSE has been part of a structure which has been different from that of independent comparative education societies, but which resembles the structure in some other countries.

The two other societies that retain very close ties to the CIESC, namely the Higher Education and Adult Education Societies, never became affiliates of the CSSE but remain independent organisations even though their annual conference coincides exactly with the dates of the CIESC/CSSE conference. There have been many discussions as to whether the CIESC should be an independent society or remain an affiliate of the CSSE. The CIESC executive was not unanimous in the decision to become an affiliate of the CSSE. The January 1973 edition of the newsletter reported (p.6) that:

The discussion among the executive committee revealed that hopes are high for the CSSE, but there are some strong reservations too. Members are urged to consider this matter very carefully.

Many members still harbour reservations, but there has been no overt attempt to secede from the CSSE. The larger CSSE association recognises the connections CIESC has to international research and development, and it is always a member of the CIESC who is named the CSSE representative to the Canadian National Commission for UNESCO. When CIDA wishes to hold a symposium during the annual Humanities and Social Sciences conference, normally the CIESC programme will list and co-sponsor the event in recognition of the ongoing work by CIESC members in CIDA projects.

The CIESC newsletter has reported on activities of members in the international education area as well as on the development of courses and programmes in comparative and international education. For example, the November 1969 issue announced McGill University's new MA in Comparative Education. It also reported that the University of Alberta was continuing with its comprehensive school training programme for experienced teachers from Thailand; and the University of Western Ontario highlighted a pilot programme for returned CUSO volunteers in which the returnees could take an intensive course to prepare them for teaching certification for Ontario schools. The newsletter has also included occasional short articles, and has been used to publish minutes and reports from the Annual General and Executive meetings, and to list members with their current research interests. A version of the newsletter was placed on line as a link to the CIESC Website (http://www.edu.uwo.ca/ciesc). 


\section{Epistemological Grounding}

Throughout its evolution and development, the CIESC has demonstrated an ongoing exploration of the epistemological base, asking what it means to engage in comparative and international education. Some members have questioned whether comparison of different regions of Canada qualifies for the field. However, as Andrew Skinner noted (1970b, p.7), in comparative education "a first essential is to know one's own system of education as thoroughly as possible, historically and contemporaneously; and second that within the provinces of Canada itself there is plenty of scope for comparative educational studies". Referring to the papers in the 1970 edition, Skinner remarked that "while there is revealed a desirable readiness now for comparative studies that range through other countries, Canada remains sensibly the essential base of reference and comparison". David Radcliffe, editor of the CIESC Newsletter in the early 1970s, reflected on the research interests of Canadian comparativists as developing "from an initial concern with our intra-confederal comparisons, to a steady broadening of interest to more international studies", citing the community education of CIDA and the evolving functions of the International Development Research Centre (IDRC), among many other indications (Newsletter, May 1973, p.2). Radcliffe also playfully commented on methodologies used in comparative education studies:

Do we detect a return swing of the pendulum, from comparative educator as key-puncher extraordinary (as a well-known educational economist said, "Many are the transgressions of those who do regressions") to Yogi-Guru? Or perhaps it is a sign of maturity when one hears a distinguished authority remark that it is time we stopped fussing about the appropriate methodology to give our discipline respectability and got on with the job; for methodology emerges naturally from the object of study.

A review of the CIESC presidential speeches may further illustrate how Canadian comparativists have viewed the inter-connection of international and comparative studies. David Wilson, a president of the CIESC (1987-1991), of the US CIES and of the WCCES, was much involved in documenting the history of the institutions, key players, and the field. In his CIES presidential address, he commented on how comparative and international education in North America merged in the 1960s (Wilson 1994a). This theme intertwines the field even today.

According to Suzanne Majhanovich (2003), president of CIESC from 2001 to 2003, a dichotomy continued to exist with the comparative side being viewed as the scientific, theoretical component focused on explaining the phenomena of the field. The international counterpart on the other hand has been associated with the practical-descriptive field-based activities including the allimportant work championing education for all, human rights, peace, and cultural understanding. Former CIESC presidents expressed concerns in research methodologies that involve comparative and international education issues in the field. For example, Douglas Ray (President 1973-1975) gave a report (1997) on the ongoing project in Russia on democracy and education, Russian-Canadian 
Cooperation in Curriculum Development: Russian Civic Education, 1990-1996 which provided an example of exemplary international research and development. Kissonpersad (K.P.) Binda (President 1999-2001) also showed this aspect of comparative and international education research when he argued the case for aboriginal education in Canada legitimised through comparative and global perspectives (2001).

These examples reflect the way comparative and international theory and practice overlap and confirm Wilson's message in his 1994 CIES presidential address, 'Comparative and International Education: Fraternal or Siamese Twins?' (Wilson 1994a). As he pointed out, "our twins have been inseparable since their birth, and both the names of each twin and their activities have been interchangeable at various periods in their life cycles" (p.483). Comparative and international education can also make important contributions to the illumination of educational policy. As David Phillips (1999, p.16) has commented, comparative data can (among other things):

- show what is possible by examining alternatives to provision 'at home';

- describe what might be the consequences of certain courses of action, by looking at experience in various countries (i.e. in attempting to predict outcomes it can serve both to support and to warn against potential policy decisions); and

- provide a body of descriptive and explanatory data which allows us to see various practices and procedures in a very wide context that helps to throw light upon them.

Phillips strongly believed that "weighing of evidence from other countries in such ways as to inform and influence policy developments at home should be a very natural part of any efforts to introduce change" (1999, p.18).

\section{Some Features of the CIESC}

At the founding meeting in 1967, the English and French versions of the CIESC Constitution were approved. The Constitution was revised in 1975 to reflect CSSE membership and was further revised in 1993. According to the 1993 version, the following are eligible for membership:

- teachers, research workers, and graduate students in comparative education, international education, development education, native education, cross-cultural education, and related fields; and

- persons working in government and non-government agencies and organisations concerned with studies in comparative education, international education, development education, native education, crosscultural education, and related fields.

CIESC members fall into four categories: regular members (who join the society as part of their membership of CSSE), student members (who are designated by their advisors who are members of the society), world members (teachers or researchers in comparative and international education who reside

8 Canadian and International Education Vol. 36 no.1 -June 2007 
outside Canada and who join by applying to the Secretary-Treasurer), and honorary members (who have rendered long and distinguished service to comparative and/or international education and related fields).

The Executive manages the business of the society between Annual General Meetings, and consists of the President, Vice-President (who is considered as President-Elect), Immediate Past-President, Secretary-Treasurer, the Programme Chairperson, and two or three Members-at-Large (who take on specific portfolios with the society such as membership, liaison with CSSE, newsletter editorship, or other tasks deemed necessary by the Executive). The President, Vice-President and the Members-at-Large are elected for a term of two years, and the Secretary-Treasurer is elected for three years. Over the decades from 1967 to 2007, CIESC members elected 21 presidents (Table 1).

Table 1: Presidents of the CIESC (1967-2007)

\begin{tabular}{lclc}
\multicolumn{1}{c}{ Name } & Years & \multicolumn{1}{c}{ Name } & Years \\
Joseph P. Katz & $1967-1969$ & Vandra L. Masemann & $1985-1987$ \\
Andrew Skinner & $1969-1970$ & David N. Wilson & $1987-1989$ \\
Lionel Desjarlais & $1970-1971$ & David N. Wilson & $1989-1991$ \\
Roger Magnuson & $1971-1972$ & Ralph M. Miller & $1991-1993$ \\
Avigdor Farine & $1972-1973$ & Deo H. Poonwassie & $1993-1995$ \\
Douglas Ray & $1973-1975$ & Eva Krugly-Smolska & $1995-1997$ \\
John R. Mallea & $1975-1977$ & Peter Fan & $1997-1999$ \\
Margaret Gillett & $1977-1979$ & K.P. Binda & $1999-2001$ \\
Shiu Kong & $1979-1981$ & Suzanne Majhanovich & $2001-2003$ \\
Daniel Dorotich & $1981-1983$ & Cecille DePass & $2003-2005$ \\
Jacques Lamontagne & $1983-1985$ & Allan Pitman & $2005-2007$
\end{tabular}

CIESC members hold their annual conference in late May or early June during the dates assigned to the Canadian Society for Studies in Education by the Congress for Humanities and Social Sciences which in 2000 took over responsibility for the Annual Congress from the Council of the Learned Societies of Canada. Following the tradition of the Learned Societies Congresses, the Conference is hosted by a different university in Canada every year. The CIESC represents the CSSE every few years in the American Educational Research Association (AERA) at the annual conference whereby each affiliate of the Canadian umbrella organisation - the CSSE - provides a dedicated session in the AERA annual programme on a rotating basis.

In 1988 the CIESC conferred its first Michel Laferrière Thesis Award in memory of a deceased member from McGill University. The first recipient of the award was Susan Bayley of McGill University. The award was conferred to the best research conducted by either a Master's student or a PhD student. Later the society decided to confer two awards: one for the best Master's thesis, and one for the best PhD dissertation. In 1990, Andrew Skinner made a monetary award to CIESC which serves as a travel stipend of Can $\$ 100$ to award winners to help them 
attend the conference. Starting from 2000, Douglas Ray also made a similar monetary contribution to fund an award to the best graduate student paper presented at the annual conference. Award winners receive a Certificate of Accomplishment and a cash award. They are also entitled to a one-year free membership of the CIESC.

\section{International Leadership}

Several distinguished leaders of the CIESC have played significant roles in the WCCES and the US-based CIES. Although the extraordinary contributions of Joseph Katz regarding the founding of both the CIESC and the World Council have been mentioned above, it is fitting to include at this point a special tribute to him because he was so central to the development of the field in Canada. Joseph Katz graduated from the University of Chicago, USA, in 1941, and started the comparative programme at the University of British Columbia, Canada, in 1956. At the founding stage of the CIESC, he was the recognised driving force. This was noted by Margaret Gillett (1988, p.3), one of the founding members and a former CIESC President, in her tribute, In Memoriam (to Joseph Katz) in Canadian and International Education:

All of us closely connected with Comparative Education in Canada will acknowledge the debt we owe to Joe Katz, for he was professionally and personally a most generous man. He gave freely of his time, energy, and inspiration to his colleagues and to the organisation to which he belonged and he was ever-ready to pick up the tab after dinner - whether it was in London, Beijing, Paris, Tokyo, or Toronto. We miss the verve with which he initiated many projects and the steadfastness with which he continued to support them.

Although the early proposal for the CIESC to have a special relationship with its US counterpart was never formalised, continuing scholarly exchanges between the two societies have benefited both organisations. The majority of CIESC members are also members of the CIES, and several Canadians have served as CIES Presidents, beginning with Joseph Katz and continuing with Reginald Edwards, Robert Lawson, Mathew Zachariah, Joseph Farrell, Vandra Masemann, David Wilson and Ruth Hayhoe. Ratna Ghosh has been a Board Member of the CIES.

Formal CIESC international linkages continue to be maintained with the WCCES with the CIESC President serving as a member of the Executive Committee. In addition to David Wilson, former CIESC President, Vandra Masemann served as President of the Council as well as Secretary General; Douglas Ray served as Chair of two World Congress Programme Committees in Rio de Janeiro and Prague, and Jacques Lamontagne was Chair of the Organizing Committee for the $7^{\text {th }}$ World Congress in Montreal, and was also Assistant Secretary General of the WCCES.

The CIESC grew from its 43 founding members through a peak of 204 members in 1989 (because of the Montreal Congress), to approximately 100

10 Canadian and International Education Vol. 36 no.1 -June 2007 
members in 2005. The capacity of the society to organise activities related to the field of comparative and international education has expanded. In 2003, a crossCanada research group, the Citizenship Education Research Network (CERN) joined the CIESC as a Special Interest Group (SIG). Their projects on citizenship education in Canada's plural and diverse society closely match the society's goals as set out in the Constitution.

\section{Special Issues of Canadian and International Education}

The development of the CIESC journal, Canadian and International Education (CIE), which was first issued in 1972, and the prior publication of conference proceedings have been described above. Both the Proceedings (Gillett et al. 1967; Braham et al. 1968; Skinner 1970) and the CIE have reflected the good health of the society, and indeed, the responsive interest of its members, while also constituting a source of comparative studies of interest to Canadian educators, as well as to readers internationally. The Journal has preserved the bilingual character of the Proceedings and is recognised and indexed internationally. The $C I E$ has published a number of special issues which have often served as resource books for comparative and international education courses.

In 1979, the CIE undertook its first special topic issue: "Education in Asia" (Volume 8, No.2), edited by Shiu Kong. Subsequent special issues have included:

- "Education and The World Bank", Volume 12, No.1 (1983), edited by Stephen P. Heyneman;

- "Development Education in Canada in the Eighties: Context, Constraints, Choices" in Volume 12, No. 3 (1983), edited by Mathew Zachariah;

- "Race, Culture and Ideology in Canadian Education" in Volume 14, No.1 (1985), edited by Richard Heyman;

- "Chinese Educators on Chinese Education" in Volume 16, No.1 (1987), edited by Ruth Hayhoe and Ralph Miller;

- "New Challenges for Development Education in Canada in the Nineties" in Volume 20, No.1 (1991), edited by Cecille DePass, John L. McNeil, and Mathew Zachariah;

- "On the State of Higher Education" in Volume 20, No.3 (1991), edited by Michel Saint-Germain;

- "Citizenship Education: Canadian and International Dimensions" in Volume 25, No.2 (1996), edited by Alan Sears, and Murray Print;

- "Multiculturalism" in Volume 28, No.2 (1999), edited by Rosa Bruno-Jofré and Evelina Orteza y Miranda.

- "The OECD Indicators. International Comparisons of Education Systems," Volume 31, No.2 (2002) edited by Nelly McEwen;

- "Educational Restructuring in the Era of Globalisation" Volume 33, No. 1 (2004), edited by Goli Rezai-Rashti.

- "Values, Human Rights and Citizenship Education in Transnational Perspectives", Volume 34, No. 1 (2005), edited by Yvonne Hébert, Glen Eyford and France Jutras. 
Indeed, the special issues of the CIE have provided a venue for some of the best work and research by distinguished Canadian Comparative Educators. It is beyond the parameters of this paper to highlight further the work of Canadian comparativists. However, to celebrate CIESC's $40^{\text {th }}$ birthday in 2007, the CIE will publish in one special issue the cumulative index of all articles that have appeared in the CIE since its inception.

While the CIE received initial and renewed support from the Canada Council, an arms length agency of the Canadian government, the journal later survived intervals without this external funding. Funding for special issues had been obtained from Citizenship and Immigration Canada, the World Bank, CIDA, and the Asia Pacific Foundation of Canada. From 1989, the Social Sciences and Humanities Research Council of Canada provided financial support under its triennial programme in support of publications. In addition, technical support and financial backing from the Faculties of Education where the Journal was housed assured its continuing existence.

\section{Continuing Challenges and the Future}

Reviewing the comparative education courses offered by Canadian universities in the early 1990s, Wilson (1994b, p.17) commented that the field was fragmented:

Most Canadian comparative educators are hired to teach courses other than Comparative Education and no stand-alone Department of Comparative Education exists in the country. While this is deplorable on the one hand, the other side of the equation is that interest in the comparative study of education is quite widespread at the Canadian post-secondary level.

A decade later, the situation had worsened in terms of the number of courses specifically designated as comparative education. Although some comparative education courses were offered by colleges rather than universities (for example Lethbridge College and Fanshawe College), and some educational courses were offered outside Faculties of Education (for example in York University, where comparative education was offered in the Faculty of Sociology), the number of courses appeared to have declined. However, this picture might have reflected changes in course names and expanded areas of research in comparative and international education. For example, at the University of Western Ontario, only one graduate course that is listed specifically included comparative education in the title but at least four other graduate courses treated areas of interest to comparative education, such as the issues of globalisation.

Comparative and international education in Canada has become an eclectic discipline in the most positive sense of the word. It is concerned with international matters and development around the world, and involves in research using a variety of methodologies into such global issues as human rights, peace studies, cross-cultural studies, literacy, numeracy, multilateral initiatives such as 'Education for All' as well as national (Canadian) education issues of second language education, immigration and the education of immigrants, citizenship, academic assessment, educational restructuring and many other issues currently

12 Canadian and International Education Vol. 36 no.1 -June 2007 
under focus in education. Hence, even if there are very few courses or programs explicitly labelled comparative education, the field pervades the study of education.

The challenges facing the CIESC in its fourth decade include increasing membership, particularly student membership; encouraging Canadian practitioners of international education to participate in CIESC activities; promotion of comparative education in all Canadian faculties of education; liaison with other learned societies interested in comparative and international studies; and coming to grips with the realties of globalisation. Comparative and international educators in Canada are active in almost every area of education, and the experience they bring from other milieu can add different perspectives lacking in those who have not been privileged to experience the world from the reality of others. This is among the strong contributions that comparativists can bring to study of any educational matter. It is the responsibility of the CIESC and its members to live up to that challenge.

\section{References}

Binda, Kissonpersad (K.P.) (2001): 'Aboriginal Education in Comparative and Global Perspectives: What has Research and Practice done for Aboriginal Education in Canada?'. Canadian and International Education, Vol.30, No.1, pp.1-16.

Braham, M., Brehaut, W., Skinner, A.F. \& Zachariah, M. (Eeds.) (1968): Papers: The International Mosaic in Canadian Education. Comparative and International Education Society of Canada.

Comparative and International Education Society of Canada. Constitution: Approved June 5, 1967. In Gillett, M., Katz, J., Lawson, R. \& Skinner, A.F. (Eeds.) (1967) Founding Papers. The New Look in Canadian Education. Toronto: University of Toronto Press, pp.18-23 (later revised 6 June 1975 and 6 June, 1993; archives of CIESC).

Farine, Avigdor (1972): 'La Politique de la Langue et de L'Enseignment au Québec'. Canadian and International Education. Vol.1. No.1. pp.51-58.

Gillett, M., Katz, J., Lawson, R. \& Skinner, A.F. (Eeds.) (1967): Founding Papers: The New Look in Canadian Education. Comparative and International Education Society of Canada.

Gillett, Margaret (1988): 'In Memoriam'. Canadian and International Education, Vol.17, No.2, pp.3-4.

Katz, Joseph (1970): 'The Purpose, Place and Program for the World Congress of Comparative Education Societies', in Proceedings of the First World Congress of Comparative Education Societies. Ottawa, Canada (mimeographed), pp.4-5.

Katz, Joseph (1972): 'A Multicultural Curriculum for a Cosmopolitan Citizen'. Canadian and International Education, Vol.1, No.1, pp.7-14. 
Majhanovich, Suzanne (2003): 'Making Sense of Decentralisation in Education Using a Comparative Lens'. Canadian and International Education, Vol.32, No.1, pp.1-18.

Phillips, David (1999): 'On Comparing', in Alexander, R., Broadfoot, P. \& Phillips, D.

(Eeds.), Learning from Comparing: New Directions in Comparative Education Research, Volume 1: Contexts, Classrooms, and Outcomes. Oxford: Symposium Books, pp.15-20.

Ray, Douglas (1997): 'Russian-Canadian Cooperation in Curriculum Development: Russian Civic Education 1990-1996'. Canadian and International Education, Vol.26, No.1, pp.1-13.

Skinner, Andrew F. (Eed.) (1970a): Papers: Comparative Studies in Higher Education. Comparative and International Education Society of Canada.

Skinner, Andrew F. (1970b): 'Foreword', in Skinner, Andrew F. (Eed.), Papers: Comparative Studies in Higher Education. Comparative and International Education Society of Canada, pp.7-9.

Skinner, Andrew F. (1972): 'Transition: A Note for the Record.' Canadian and International Education, Vol.1, No.1, p.4.

Wilson, David (1994a): 'Comparative and International Education: Fraternal or Siamese Twins? A Preliminary Genealogy of Our Twin Fields'. Comparative Education Review, Vol.38, No.4, pp.449-486.

Wilson, David (1994b): 'On Teaching the Methodology of Comparative Education: Why are there so few Courses in Canada?'. Canadian and International Education, Vol.23, No.1, pp.13-24.

Suzanne Majhanovich is a Professor at the Faculty of Education, The University of Western Ontario. Current research interests include international language policies, globalization and decentralization. She edits Canadian and International Education.

Zhang Lanlin graduated from the doctoral program of the Faculty of Education, The University of Western Ontario in 2005. His research interests include international education, cross cultural language education, English as a Second Language theory and pedagogy and Chinese culture. Email: 1lzhangg@yahoo.com 